\title{
Wayfaring in Taiwan during COVID-19 Reflections on Political Ontologies of Disease and Geopolitics
}

\author{
Scott Simon \\ University of Ottawa
}

\begin{abstract}
What are the political and ontological implications of COVID-I9? I had plenty of time to reflect on this from March to July after I ended fieldwork in Guam and unexpectedly spent four months in Taiwan. Because of Taiwan's proximity to China, where the pandemic began, it initially seemed as if it would be among the most serious cases. Instead, Taiwan's public health measures allowed it to become one of the few places in the world relatively untouched by the virus. The experience of Taiwan with COVID-I9 was shaped most of all by tense relations with China and the non-recognition of the country by the World Health Organization (WHO). There are also intriguing differences within Taiwan where historically Chinese settler groups and Indigenous peoples related to other Pacific Islanders find their place in the world through a broad spectrum of non-Western ontologies. In travelogue genre, I reflect upon their different stories and practices of worlding as fears of the pandemic contributed to a heightened sense of crisis, ethnic tensions, and a rise in nationalism. This reveals important ontological differences that will continue to influence the geopolitics of the region even beyond the current pandemic.
\end{abstract}

Keywords: Taiwan; COVID-I9; geopolitics; political ontology; Indigenous peoples

Résumé: Quelles sont les implications politiques et ontologiques de la COVID-I9? J'ai eu tout le temps de réfléchir à cette question entre mars et juillet, lors d'un séjour impromptu de quatre mois à Taïwan, à la suite de mon travail de terrain à Guam. Du fait de la proximité de Taïwan avec la Chine, où et née la pandémie, il semblait au départ que ce pays serait l'un des plus atteints par la pandémie. Au lieu de cela, grâce aux mesures de santé publique mises en œuvre par l'État, Taïwan est devenu l'un des rares endroits au monde à être 
relativement épargnés par le virus. L'expérience taïwanaise de la COVID-I9 a surtout été marquée par des relations tendues avec la Chine et par la nonreconnaissance du pays par l'Organisation mondiale de la santé (OMS). Par ailleurs, il existe des différences intéressantes à Taïwan entre les descendants de Chinois et les peuples autochtones liés aux autres sociétés insulaires du Pacifique, deux groupes qui se font une place dans le monde au moyen d'un large éventail d'ontologies non occidentales. Sur le mode du récit de voyage, j'interroge les différents récits et pratiques de production du monde qu'ont développés ces groupes alors que les craintes suscitées par la pandémie contribuaient à accroître le sentiment de crise, aux tensions ethniques et à la montée du nationalisme. Cette réflexion révèle d'importantes différences ontologiques qui continueront d'influencer la géopolitique de la région même au-delà de la pandémie actuelle.

Mots-clés: Taiwan; COVID-ı; ; géopolitique; ontologie politique; peoples autochtones

\section{Introduction}

COVID-I9, coronavirus SARS-CoV-2, or (in a Trumpian world) the "China Virus" is unsettling the comfortable ontological assumptions with which we began the twenty-first century. One lesson from the 2003 SARS crisis and the current pandemic is that networks of live animal markets, migration and air travel connect us humans - via viruses - to the lives of wild bats, civets, and pangolins in potentially lethal ways. The idea that viruses also have geopolitical implications has entered anthropological discussions around COVID-I9. In an early reflection on the meaning of COVID-I9, Arjun Appadurai speculated that COVID-I9 "knocks on the door of the Westphalian model of sovereignty in a way that Ebola, SARS, and HIV did not" (Appadurai 2020, 222). His argument is that, even in China and other countries that took draconian measures against contagion, state policies are effective only due to social mobilization. The power of society thus triumphs over the dominance of Leviathan. Based on what I observed in Taiwan, I think that his argument can be pushed further by looking at what it reveals about ontological difference. COVID-I9, as it spreads through multiple ontologies, can become a catalyst in Indigenous and other national resurgences that can "trouble politics," to borrow words from Mario Blaser's speculation about new diseases (Blaser 2014, 50).

In this essay, I reflect upon COVID-I9 as an ontological issue that I encountered while on an expected four-month stay in Taiwan from March to July 2020, 
as the first wave of COVID-I9 engulfed the world. Ontology, the metaphysics of what is or what things are, has opened up fertile new discussions in anthropology, especially on the borders between Indigenous and non-Indigenous worlds (Descola 20I4; Viveiros de Castro 2009). Writing about Taiwan is not new to me. ${ }^{1}$ I write not only from my wayfarings during the pandemic, but also from experiences of doing field research in Taiwan in both non-Indigenous and Indigenous communities since 1996, and from making Tainan my second home through marriage. I find it appropriate to think about the different ways in which different peoples live COVID-I9 in terms of what Mario Blaser and Marisol de la Cadena call Political Ontology (capitalizing both words) as "the divergent worldings constantly coming about through negotiations, enmeshments, crossings, and interruptions" (Blaser and de la Cadena 20I8, 6). I argue that Indigenous peoples have always been knocking at the doors of the Westphalian powers, convinced of their own ontological status as nations whose sovereignties have been disregarded for far too long. In the case of Taiwan, Indigenous peoples seek recognition of rights and sovereignty in a nation-state that is itself not widely recognized in the jungle of the Westphalian inter-state system. COVID-I9 renders visible those ontological entanglements.

At the time of the 2003 SARS crisis, Foucauldian concepts of biopolitics and governmentality proved to be fertile ways of understanding the health crisis that hit China, Taiwan, and Canada. Geographer Bruce Braun argued that the governmentality of infectious disease led to two reactions. The first was a molecularization of life that intersected with the individualization of risk, as individuals were expected to take responsibility for their own health. The second is public health concerned with "biosecurity" to mitigate the sanctity of borders and foreign risks (Braun 2007). The main players in the first are individuals; whereas those in the second are states, including Canada's Global Public Health Intelligence Network (GPHIN), and the international health bureaucracy such as the World Health Organization (WHO). In this kind of logic, Canada's failure to contain COVID-I9 in the early days of the pandemic might be attributed to insufficient use of masks and social distancing among the general public and/ or the 2019 curtailment of the GPHIN's international pandemic surveillance activity (Robertson 2020). Adding to this, an ontological perspective allows us to question what is. In a naturalist ontology, the pandemic is above all a pathogen that exists outside of humans; and which must be prevented from crossing human-nonhuman borders through state policy and individual behaviour modification. Braun's observations conform to that ontological presumption. In 
Taiwan, I perceived how this ontology intersected with two other ontologies in ways that, as Political Ontology hopes, destabilize established political orders. How do Han Taiwanese (Chinese?) and Formosan Indigenous ontologies of disease trouble the politics of the international system?

\section{Writing as Travelogue: A Methodological Note}

Because of the sudden emergence of COVID-I9, I did not have the luxury of immersing myself in the relevant literature of medical anthropology for months and planning a systematic research project. Quite importantly, I could not apply for the ethics approval needed to interview people about their views on the pandemic. I thus have no choice but to write from my own personal experience. This type of peripatetic method, learning by wayfaring, has nonetheless always been at the core of ethnographic fieldwork, usually called "participant observation." This method, combined with a writing as travelogue, brings to light important political and ontological differences between Taiwan's Indigenous and non-Indigenous peoples. The writing genre is important, as a strategy to show how my understandings unfolded over time as I emerged from quarantine and eventually dared to travel domestically in Taiwan.

I had planned to be elsewhere, on another research project. I had intended to spend January to June doing research on the island of Guåhan (the unincorporated US territory of Guam) with the CHamoru people as part of my research project, "Austronesian Worlds: Human-Animal Entanglements in the Pacific Anthropocene." For family reasons (see below), I began my year in Taiwan and flew to Guåhan from there on the direct flight on China Airlines. In addition to doing research, I taught a class at the University of Guam. On I5 March, the first COVID-I9 cases were discovered on Guåhan and, not directly related to that, I received instructions from the University of Ottawa to stop research and return to Canada. I changed my return flight to I7 March, not knowing that it would be China Airline's last flight from Guåhan nor that Taiwan would close its borders to non-residents on the following day. As international aviation shut down, I found myself stuck in Taiwan and continued teaching on-line. This gave me the opportunity to experience COVID-I9 from both Holo-dominant Tainan, where my family lives, and in the Indigenous communities I visited. I returned to Canada in July. This article was my quarantine project. 


\section{Introduction to Taiwan: Indigenous and Non-Indigenous Peoples}

Taiwan is an interesting place from which to think about COVID-I9, firstly because of its success in controlling the virus (Cole 2020, Lo 2020), in spite of (or because of) Taiwan being excluded from the WHO for political reasons (see below). By 23 July, when I first wrote this article, Canada (population 37.59 million) had over II3,00o confirmed cases, whereas Taiwan (population 23.57 million) had only 455 confirmed cases and 7 deaths. Taiwan's Centres for Disease Control (CDC), in their daily Twitter update, classified these as 364 imported (jingwai), 55 local transmission (bentu), and 36 military cases. As I revise on I3 November, the John Hopkins coronavirus tracker reported that Canada has 285,936 confirmed cases and Io,828 deaths, compared to 589 cases and seven deaths in Taiwan. Canada seems poised for a winter surge and painful lockdowns, whereas life in Taiwan continues as normal. This is especially impressive when one considers that Taiwan $\left(36,193 \mathrm{~km}^{2}\right)$ is roughly the size of Vancouver Island, consists mostly of sparsely inhabited mountains, and has very high population density in urban areas. Taiwan's proximity to China, where the disease first broke out, made Taiwan more vulnerable, but may also explain why Taiwan reacted so quickly to stop its spread. Unlike Canada, Taiwan trusted neither China nor the WHO, an existential situation that made Taiwan one of the first jurisdictions in the world to try to stop the virus at its borders. Sociologist Lo Ming-cheng (2020) argued that Taiwan successfully mobilized state resources and societal compliance to health measures due to Taiwan's previous experience with SARS, international isolation that makes self-reliance necessary, and excellent healthcare infrastructure. I argue here that this success was also enabled by underlying ontologies of disease that predisposed people to perceive the virus as a foreign entity that can be expelled by ritual and social means.

Taiwan is an important geopolitical case because, although it is one of the world's strongest economies and has an autonomous, democratically elected government, it remains excluded from UN agencies, including the WHO. The reason is simple. China aspires to annex Taiwan, which it has never ruled, and has not ruled out possible use of military force. China thus seeks everywhere to undermine Taiwan's international legitimacy. Under a "One China" principle, states that recognize China comply with China's requests to maintain only "substantive" (but often economically important) relations with Taiwan. Taiwan, under the name Republic of China (ROC, the state that fled from China to Taiwan at the conclusion of the Chinese Civil War in 1949), as of October 2020 maintains diplomatic relations with only the Vatican and I4 countries. ${ }^{2}$ The 
Republic of China, one of the founding states of the United Nations and related international organizations, was slowly replaced in the international system by the People's Republic of China. That left the people of Taiwan, who were not consulted in the first place about the imposition of the ROC on their territory in the 1940 , in the lurch. An unstable peace reigned as long as both sides interacted in a "Greater China" framework in which civilizational tropes and flows of people seemed more important than Westphalian norms of exclusive state-based sovereignty (Callahan 2004, xxi). China even briefly permitted Taiwan to hold observer status at the World Health Assembly of the WHO from 2009 to 2016 (Chen 2020, II).

Taiwan's democracy poses a challenge to the "Greater China" framework. In 20I6, Taiwan elected President Tsai Ing-wen from the Democratic Progressive Party (DPP), a party that affirms Taiwan's sovereignty. China has since tightened pressure on Taiwan by excluding it from more international organizations, including non-governmental organizations, forcing foreign states and companies (including Air Canada) to refer to Taiwan as a "Province of China," and by poaching diplomatic allies (Rawsley 2020, I). Nowadays, China does everything possible to drive a wedge between Taiwan and other countries; and even coerces international publishers to deny its independent existence. Because Taiwan exists in the shadows of the international system, William Callahan calls it an "outlaw" (Callahan 2004, 228). In this context, COVID-I9 emerges as a symbol of Taiwanese resistance to China. In Taiwan, the disease is widely called the "Wuhan pneumonia" or even the "China virus."

Taiwan is far more complex than its post-war entanglements with China. Ever since it was administered by Japan (1895-1945), Taiwan has been under a form of biopolitics that Paul Barclay calls "bifurcated sovereignty" (Barclay 2018, 13). The majority of Taiwanese people are descendants of colonists who arrived from China in the seventeenth century, when Dutch colonization made it safe and lucrative to do so, eventually settling the fertile coastal areas and often marrying local women. In English, these peoples, who are classified by language and place of origin as either Holo or Hoklo, are usually referred to as "Native Taiwanese." This understanding contrasts them to the Mandarin-speaking "Mainlanders" who started arriving in 1945 (after Japanese defeat in WWII) and who, in spite of their numerical minority status (at most $15 \%$ ), historically dominated the ROC state apparatus (Gates I98I), at least until democratization. The Mainlanders inherited from the Japanese the roles of administrators and modernizers, whereas the land-holding Native Taiwanese focused their energies on 
farming, fishing, small-scale entrepreneurship and manufacturing, and to temple networks that the Mainlanders often disparaged as superstition.

Barclay referred to bifurcated sovereignty because an externally-imposed state governed the Native Taiwanese differently from the Austronesian-speaking peoples. The Austronesians, linguistically and culturally related to other Pacific Islanders, have inhabited the island for circa 6,000 years and still claim more than half of it as their traditional territory. In what has evolved into a politics of indigeneity, there are now 30 "mountain townships" in which Indigenous peoples live on reserves with usufruct rights and hold the reins of local political power. They have a guaranteed quota of six seats in the legislature, three to represent peoples of the mountain townships and three to represent peoples in lowland townships, where individuals have private property rights and live in more ethnically diverse settings. Only Indigenous people have their ethnicity labelled on identity cards and household registration records, as they are entitled to certain state benefits. As of September 2020, 575,555 Indigenous people (2.5 percent of Taiwan's population) were classified into I6 officially recognized peoples.

The new ontological approach in anthropology fits uneasily with received ways of studying Taiwan, which means one must read between the lines of existing ethnographies. During the Cold War, anthropologists working on Taiwan generally focused on the non-Indigenous groups, looking for manifestations of Chinese traditional culture, an approach which has been questioned, even dismissed as Orientalist (Murray and Hong 1994), for over two decades. Working with bird-watchers and thinking through issues of avian flu in Taiwan and Hong Kong, Frédéric Keck argued that birders act as sentinels, protecting their habitats against external threat (Keck 20I5). Paul Katz, carefully problematizing the method of comparing contemporary Taiwan to classical Chinese texts, has studied temple rituals of the plague-related deities Wangye, which are among the most prevalent deities in Taiwan, perhaps outnumbered only by ubiquitous earth gods. Katz observed Wangye triennial festivals in 1985, 1988, I99I, and 1994 in Xigang and Donggang, both near Tainan (Katz 1987, 1995). Chinese colonists brought rituals of appeasing deities or demons with them from Fujian as they settled the disease-ridden island of Taiwan. The festivals culminate with placing images of the Wangye on a boat which is either floated out to sea or burnt. The popular Dragon Boat festivals also originated in anti-epidemic rituals (Katz 1987, 205). From an ontological perspective, we could say that infectious disease is foreign. The settlers, aware that they were arriving in a foreign land, referred to 
disease as shuitu bufu ("unable to cope with the land and water"). But, with the proper rituals, disease can be exorcised and expelled beyond the newly-secured borders (Katz 1987, 198). A similar ontology of disease seems to be reflected in the language of the COVID-I9 epidemic, as cases are classified as being either jingwai ("outside the boundaries") or bentu ("this soil"). Both Keck and Katz reveal a constellation of ideas by which land can be secured, sentinels are needed, and impurities can be expelled or kept at bay.

Since ontologies arise from embodied experience, the fact that Taiwan was settled from outside is important. To understand settler perspectives before segueing to Indigenous ontologies, a quote from Qing dynasty settler Liu Zhiwan seems pertinent:

"This year we moved inward, surrounded and defeated the aborigines, and started to cultivate the land. Fording rivers and climbing mountains, we faced thousands of perils. And on top of all the suffering the soldiers endured came disease, which spread to such an extent that only 27 men in the entire camp remained unaffected" (Katz 1987, 198).

The "aborigines," now recognized as Indigenous peoples, have their own ontologies of disease, as first documented by Japanese anthropologists. Most anthropologists of the time mentioned infectious disease and epidemics only very briefly, as a "reason" for which different groups would launch head-hunting expeditions and rituals (Simon 20I2b, I74-I75). Japanese police records show a dramatic spike in head-hunting near the end of the I918-1920 Spanish Influenza epidemic (Simon 20I2b, I79). Gui Giling, Paiwan elder and President of the Indigenous Medical Association, also once told me about the connection between pandemics and head-hunting as a pan-Indigenous historical practice. There was obviously a very ancient understanding of infection. The Atayalic groups, for example, avoided other settlements if infectious diseases were present and avoided sitting around a fire with or sitting in a place where an ill person had sat previously. The greatest fear was smallpox (Kojima 1996, 50). When I did fieldwork in Sejiq/Truku communities, people explained that in the past they believed epidemics were caused by a loss of spiritual equilibrium in the community, and they would thus need to acquire new utux (usually translated as "ancestral spirit") by bringing a head into the community and making it one of their own in ritual. Paiwan communities likewise cut off all contact with infected communities. With an understanding that infectious disease was caused by demonic forces, each community had its own variants of collective rituals done to prevent epidemics from entering or to expel those that had 
already arrived (Kojima 2003, I64-I66). A difference in emphasis reveals different ontological approaches. In the Indigenous ontologies, community equilibrium and resilience are emphasized; the absence of disease is evidence that communities are strong and, in Sejiq/Truku vocabulary, have fulfilled the requirements of the ancestral law of Gaya. The settler ontology is more about securing land and expelling foreign bodies. Both these ontologies bring communities together through ritual. These ontologies have different implications for imagining sovereignty.

\section{Travelogue and Photo Essay}

\section{January: Before the Pandemic}

I arrived in Taiwan with Ma Chih-kai (Kai), my husband of I7 years, on the Air Canada flight from Vancouver on 4 January. As the passengers left the jet bridge, we were given a green card as part of the habitual public health control. Passengers from the Middle East would be given extra screening for MERS (Middle East Respiratory Syndrome). We passed the health station, where all arriving passengers are scanned for fevers and treated carpets remove potential pathogens from the soles of their feet, as part of the arrival routine. We moved quickly passed the arrivals from China, who were in a separate lane because each bag had to be searched carefully for pork products that might carry swine flu pathogens. The line was full of Taiwanese people who work in China and were returning to vote in the January II elections. There were no Chinese tour groups, who on previous arrivals took up so much space in passport control lines for non-citizens, because of the same election. China had suspended group tourism to Taiwan both to prevent their own citizens from observing the democratic practice first-hand and to give the Taiwanese a warning that there would be economic sanctions if they elected a government that sought "Independence" rather than economic integration with China. Kai and I headed straight for his hometown of Tainan.

Our brief stay in Tainan had two purposes. On 7 January, we registered our marriage with Tainan household registration authorities. I legally assumed a Chinese name, as required by law, and registered as a same-sex spouse on the household registration records of Kai's father. I was now officially a member of a Tainan family. On II January, Kai voted in the election. In the intervening days, we observed electoral events and took photos as two presidential candidates visited Tainan. Some of the candidates handed out facial masks with their campaign information, as a gift in preparation for the flu season. There was already 
news about a SARS-like disease in Wuhan, and concern about the health of Taiwanese living there, despite Chinese assurances that there was little evidence of human-to-human transmission. Taiwan's Centre for Disease Control, on 3I December, alerted the WHO of the threat (CDC 2020), but the risk seemed distant to us personally. On the evening of II January, we even celebrated with the crowds at the election headquarters of legislator Wang Ting-Yu, where no-one seemed to give thought to wearing a mask (see Figure I). Tsai Ing-wen, whom the Chinese despised as a "separatist," won the election with a resounding majority. She was still more known for her feminist stances, including promoting LGBT rights, than for public health measures. I went to Guam on I2 January, completely ignorant of the fact that Taiwan's first case of COVID-I9 was arriving from Wuhan on that same day or that Toronto would have its first presumptive case a few days later.

Taiwan had an early start in preventing an epidemic. Taiwanese authorities learned from Taiwanese people living in Wuhan about the contagious nature of COVID-I9 in late 2019 when high risk was still denied by Chinese authorities and debated at the WHO. Taiwan began screening arrivals from Wuhan on 3I December and restricting entry of Chinese nationals on 26 January; at a time when the WHO and Canada opposed such measures as racist. Even before the pandemic, Taiwan had functioning public health measures, including staffed stations to screen arrivals at airports, which meant they had to reinforce practices in place rather than scramble to create entirely new measures. As an island, there are no other ports of entry. In retrospect, people remarked that Taiwan is lucky China had banned tourism to Taiwan in the weeks leading up to the election. In Guam, when I read in the news from that Taiwan started restricting entry of Chinese nationals on 26 January, I thought everything was under control.

\section{March: Accidental Ethnography under Quarantine}

March brought increasing concern around the world about atypical pneumonia. In Guam, people started to fear contagion from Korean and Japanese tourists. On 2 March, I noted in my field notes that the Korean tourists had disappeared as suddenly and as completely as migratory birds in the fall. Panic buying began, which meant I was unable to find masks or hand sanitizer. Yet, even as every conversation seemed to turn to COVID-I9, I was able to maintain a routine

of meeting with CHamoru cultural workers and activists; and even attended a heritage hike to Ritidian Point on I4 March. On I5 March, as I was heading to 


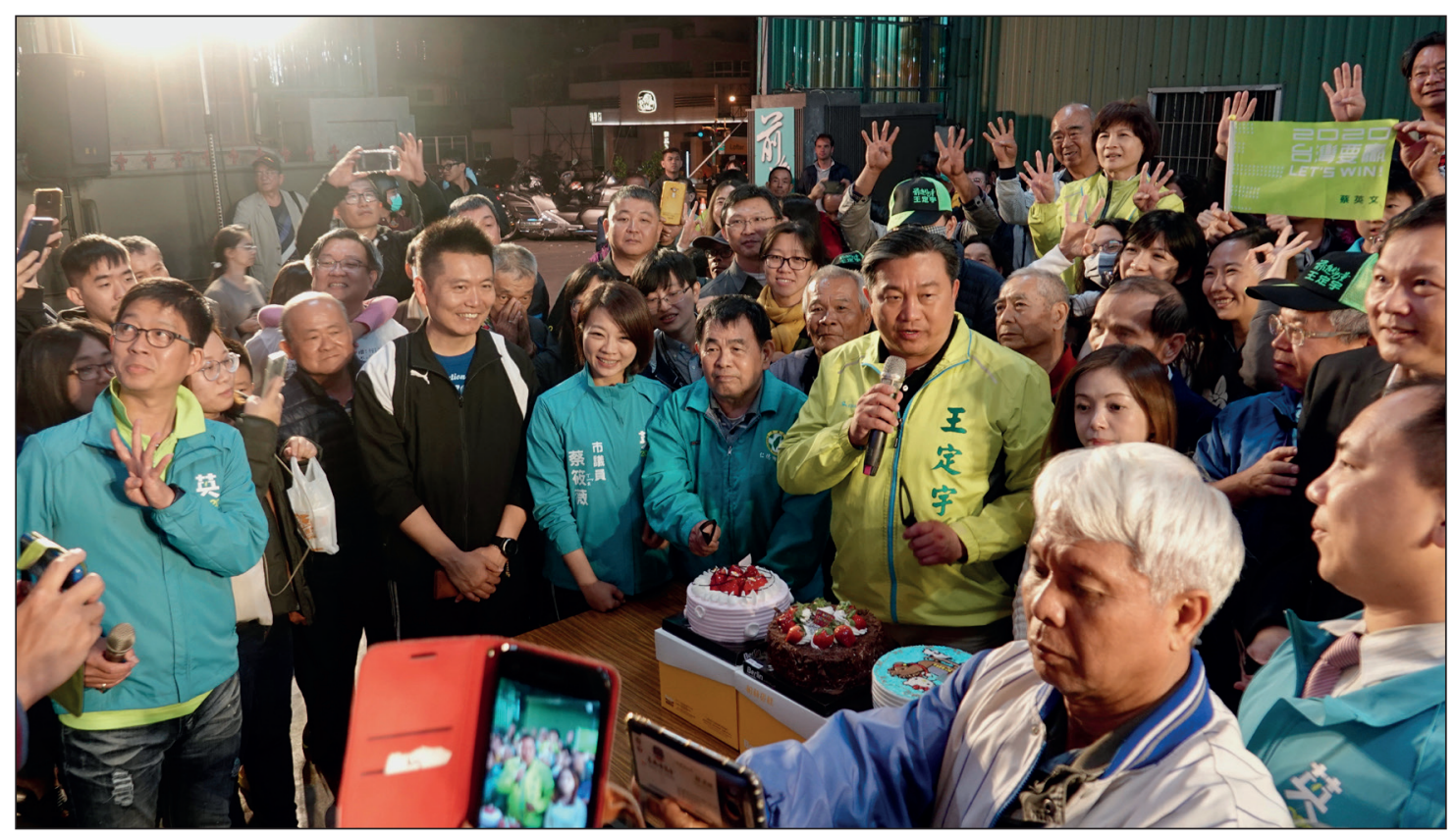

Figure 1: Before the storm: Celebrating election results in Taiwan, January 11, 2020. Photo by author.

the Guam Museum for a documentary film about the US military presence on Guam, a graduate student called and told me that the first cases had been detected on the island; and that Guam would go into lockdown. People were terrified that the island's hospitals would be overwhelmed and that food imports from the US would break down. On the same day, I received directives to return to Canada if possible. On I6 March, the University of Guam decided to close campus and teach online. Considering my precarious housing, having rented a room with neither Internet nor cooking utensils, I decided to head back to Taiwan on the next flight.

On 17 March, I returned my rental car and joined about 35 anxious Taiwanese people, carefully masked, for the China Airlines flight. Noticing that I did not have a mask, another passenger gave me one. When we arrived in Taiwan (see Figure 2), we were given green clearance because we were arriving from Guam; but on that day, Taiwan started sending all arriving passengers from 20 Eurasian countries, as well as three American states, directly into quarantine upon arrival. The red line was crowded with arrivals, some of whom appeared to be in a state of panic and even tried to force their way into the green line. Immigration officials took my address and cell phone number to transfer to health authorities, but let me head to Tainan on my own. On that date, Taiwan had an accumulated number of 77 confirmed cases and Canada had 566. On the following day, Taiwan closed its borders to non-residents. Two days later, as 
authorities realized the geographical breadth of the risk, all recent arrivals from the United States, including Guam, were retroactively asked to quarantine until I4 days after arrival. I spent the next eleven days watching birds from the balcony (see Figure 3) and reading the newspaper, which had details about each new case. I was relieved as no cases arrived from Guam.

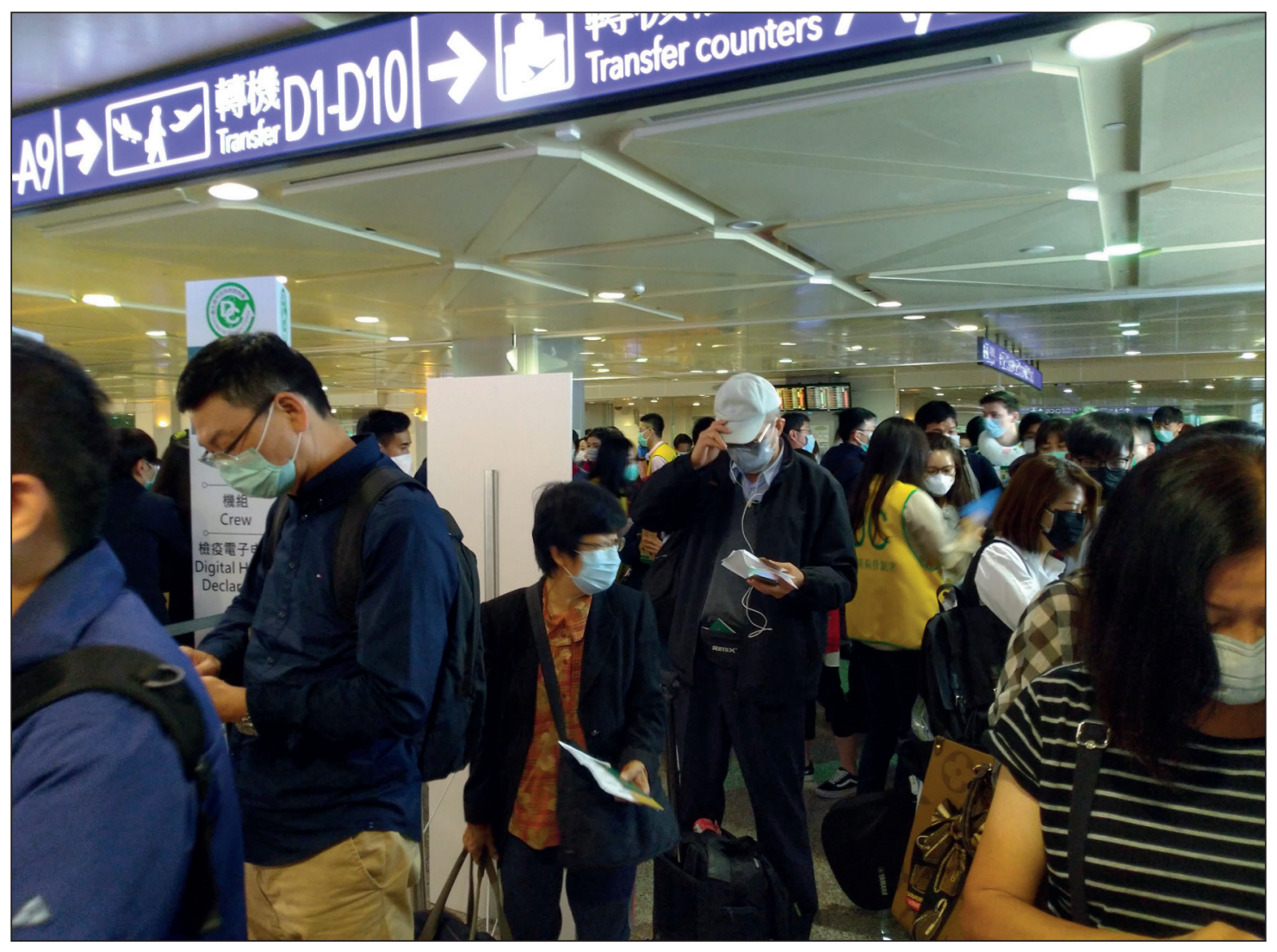

Figure 2: Anxious arrival at the airport, Taoyuan, 17 March. Cellphone photo by author.

March was a worrisome time, as tens of thousands of people returned from abroad. Minister of Health and Welfare Chen Shih-chung, head of the Central Epidemic Command Centre (CECC), became the public face of pandemic control with a daily press conference on television and social media. People made a pun from his name, which sounds like the Mandarin word for clock (shih-chung), saying that people who follow his instructions are "moving clockwise" and those who fail to obey instructions are "moving counter-clockwise." People were instructed to wear masks indoors, especially on public transportation, and maintain social distance. Large public events were cancelled or postponed. Just as Braun had described in Canada during the SARS pandemic, a modernist understanding of biopolitics based on border control and individual health and sanitation measures seemed to prevail. If there was an ontological 
difference to be found in the public face of the pandemic, it was most visible in different understandings of what is a facial mask. Unlike in the West, mask wearing was not considered to be a strictly individual measure, with the corollary that enforceable laws requiring masks violated individual freedom. They were not even seen primarily as a way of protecting the wearer. Rather, masks were seen as a way in which people could act collectively to protect others as they shared crowded spaces. In a different context, anthropologist Paul Festa argued that this Taiwanese habitus of self-abnegation in favour of compassion for others (ren) and correct principles ( $y i)$ is a modern scientific repackaging of deep-rooted Confucian ethos (Festa 2007, 105). But, as Chen and his co-workers appeared on television in white lab coats, the epidemic appeared strictly as a medical issue to be controlled by modern science.

During quarantine, I observed as media attention to imported cases led people to perceive contagion through folk sociological interpretations. My mother-in-law cursed at news broadcasts about state-sponsored evacuations from Wuhan, saying those businesspeople "should just stay in China if they think it is so wonderful." Having worked most of her life as a worker in the garment industry, she was furious that the state would rescue factory owners who had moved production from Taiwan to China in order to reap savings from lower labour costs. I was anxious about the wedding feast which my relatives were planning for a cousin, because I knew that large social events were being cancelled. I pleaded with aunts and cousins to cancel the event. "Most of the cases are in Taipei," a cousin (who majored in anthropology) assured me, "because those people returning from abroad live mostly there. The disease won't come down south." After the banquet, they assured me that the banquet had been held outside, and social distancing meant that only five people were seated at each table rather than the traditional ten. To my relief, nobody got sick.

\section{April: Epidemic and Rumours of War}

April was filled with anxiety about the pandemic and its geostrategic implications. On 3I March, over Ioo sailors docked in Guam on the USS Theodore Roosevelt tested positive. Since these aircraft carriers are perceived as part of the defence of Taiwan against China, Taiwanese media reported the unfolding of events in detail. Friends contacted me in concern, telling me that I am lucky to have left Guam. ${ }^{3}$ Rumours spread that China had intentionally deployed COVID-I9 as a biological weapon against US forces in preparation for an attack on Taiwan. When I expressed concern about Chinese military incursions near 


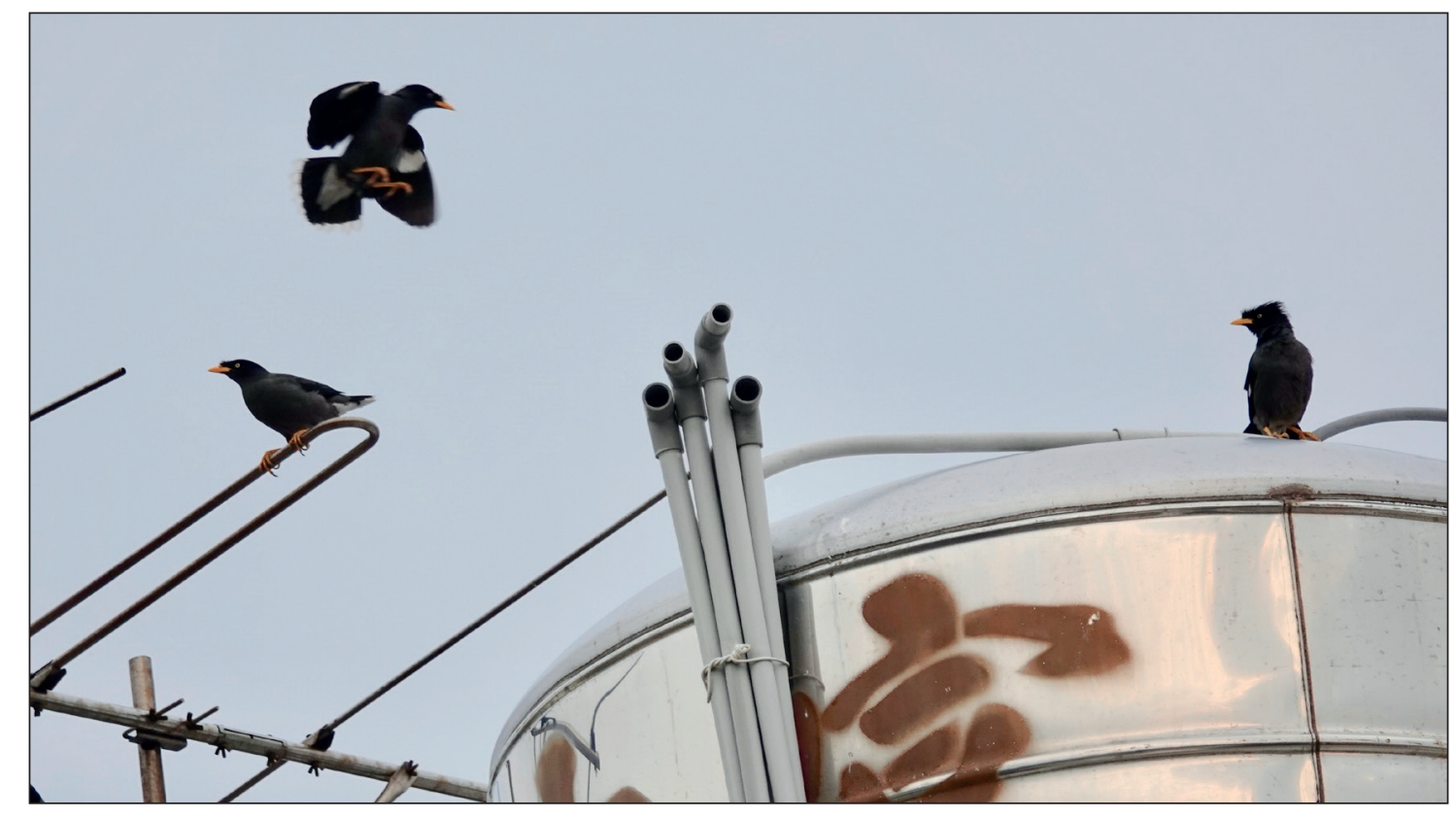

Figure 3: The view from Quarantine, Taiwan, 30 March. Photo by author.

Taiwan and Japan, my mother-in-law dismissed such concerns. "Don't worry," she said. "The Chinese are not going to invade. They have been talking about this for the past 70 years and nothing has ever happened."

The danger of military-based pandemics arrived closer to home when 27 sailors returning from Palau (with which Taiwan maintains diplomatic relations) tested positive. As soon as the results were known, the infected sailors reconstructed their on-shore itineraries from memory and cell phone itineraries. The CECC broadcasted the details through media and used cellphone apps to track people who had been in the same places. I was dismayed to learn that one sailor had spent two hours in the Mitsukoshi Department Store on I6 April, exactly one day before I had been there, and on the same floor. The department store had to close one day for disinfection; and I began daily temperature checks.

My time in Tainan brought me back to familiarity with that milieu. Each morning, I exercised in the park with the neighbours, an experience that immersed me in lifeworlds of people who speak only Holo in their daily lives. Some refused to speak Mandarin to me at all, whereas most switched politely to Mandarin after my rusty Holo assured them that I respect their linguistic preference. I accompanied my father-in-law on a weekly road trip through rural southern Taiwan. Because he is an artist specializing in Buddhist iconography, we visited many temples. For me, the highlight was a visit to a shrine in the Tainan foothills in which the Chinese Earth God and the Indigenous Siraya 
fertility deity are worshipped on one altar. My father-in-law explained that the modern Taiwanese are the offspring of intermarriage between the Holo from China and the local Siraya; and hence, as Melissa Brown (2004) argued, culturally distinct from the Chinese. Fearing infection, we avoided crowds and brought food to eat outdoors. Some of the temples had strict rules about wearing masks and cancelled group activities; whereas others continued life as if there were no pandemic at all.

During these temple visits, I paid attention to the plague Wangye deities, wondering if this was the time to hold rituals against COVID-I9, but saw no evidence that anyone was paying special attention to Wangye. On Facebook, one of the temples studied by Katz simply warned people to stay away from crowded places and to instead use their on-line services (Donggangzhen 2020). In an Internet search, I learned that the Qieding temple (see Figure 4) formerly held plague rituals, the last one having been held in 20I2. The website even said that, due to post-war improvements in sanitation and the spread of knowledge about infections, the ritual of sending off epidemics is replaced with thanks for the harvest and prayers for peace (MOI 2020). This is consistent with Katz's argument that people played down the connection with epidemics, as society had changed (Katz 1987, 212). In Tainan, I walked into one small storefront temple dedicated to Wangye. When I asked the temple manager if they plan to hold ceremonies against COVID-I9, he matter-of-factly just said no. In the news, however, I read about a Wangye temple in Taichung that held a three-day antiCOVID-I9 ritual (Xu 2020). Perhaps the temples had no need to conduct expensive exorcism rituals in a context where there were very few cases of infection and the epidemic seemed to be well controlled by the actions of the state.

My appearance in temples attracted attention. Some people gently inquired how I could enter Taiwan when the country is closed to foreign visitors. I reassured them that I entered before the prohibition and had respected quarantine instructions. Even more, people watched carefully to ensure I followed proper temple protocol, for example, entering from the righthand door, never turning one's back to the god, and refraining from lingering near the door. My mother-in-law, while visiting a temple in Qieding to pray to the goddess Matsu, knew that the best way to deal with sensitivities was to place three sticks of incense in my hands and ask me to pray. I wondered if the ubiquity of local Earth God temples can explain why locality is expressed through an idiom of the soil, even when describing COVID-I9. At the same time, as a scholar of Indigenous Taiwan, I was aware that temples are part of a history of displacing Indigenous 
peoples from their lands. Some temple histories, always inscribed in stone near the front of each temple, even say the temple was built in thanksgiving for having protected the community from "savage harm" (fanhai). From an ontological perspective, thinking about what is, these temples are a form of worlding that include demarcation of space, efficacious and potentially dangerous deities, as well as surveillance of pollution and foreign bodies. These temples also mark territory as non-Indigenous. Indigenous communities have churches.

My Indigenous friends, following my itineraries on Facebook, encouraged me to visit them. Reflecting on the Canadian history of Europeans unintentionally infecting Indigenous people, I worried about possibly picking up the virus on public transportation, and then infecting vulnerable people in their villages. My friends thought I was concerned about myself, and jokingly assured me that they would provide enough alcohol to disinfect me from any virus. One person boldly stated, "We (Indigenous people) won't get the virus anyway. We are strong. Not a single Indigenous person got SARS." Nonetheless, I dared not take public transportation until the CDC indicated that there had been 30 days without community infection.

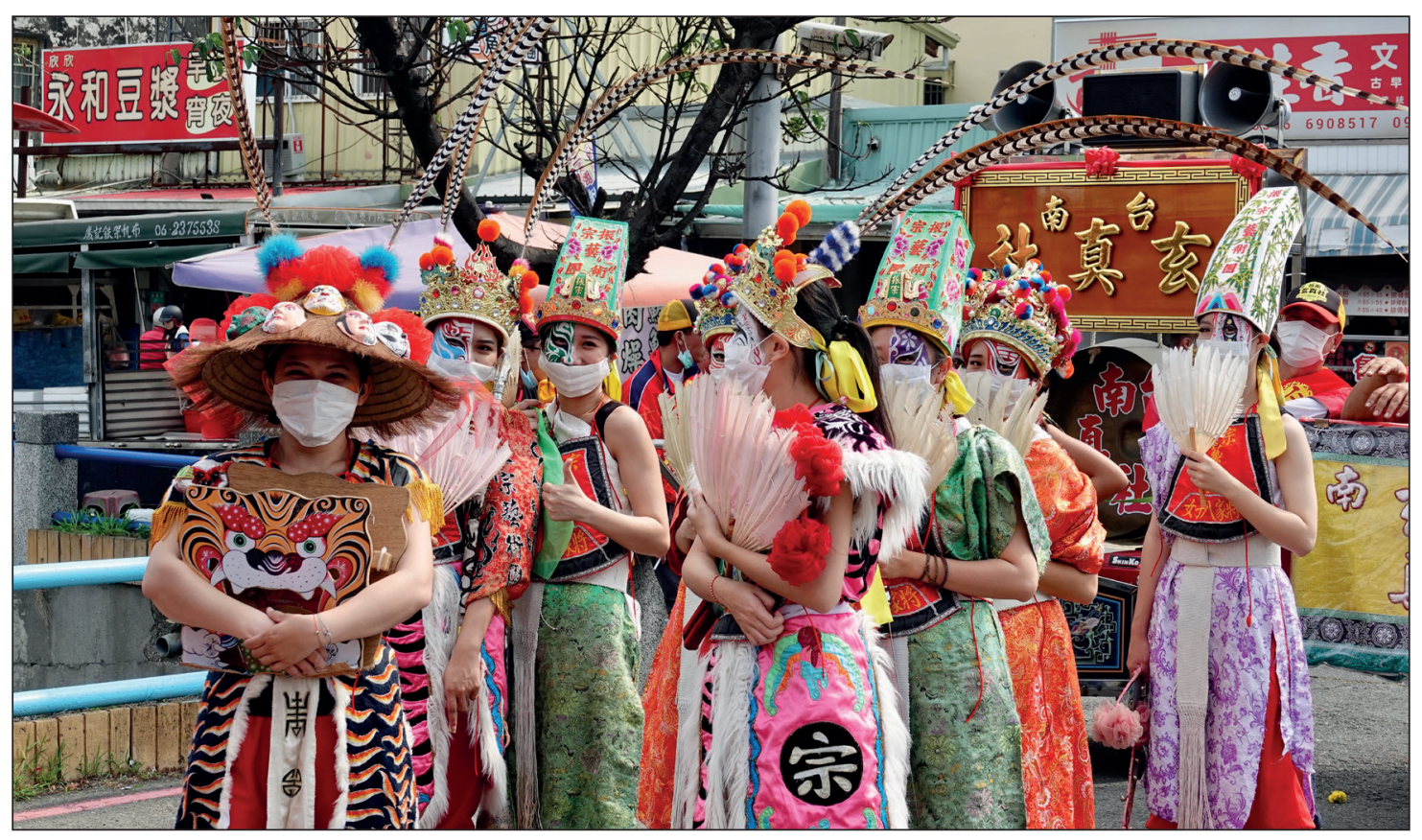

Figure 4: Temple Fair, Qieding, 4 April. Photo by author. 


\section{May: Cautious Emergence and Two Affirmations of Sovereignty}

In May, as nearly half of humanity sheltered in place, Taiwan cautiously embraced life as normal. On I4 May, I dared to travel by train to Hualien, on the opposite side of the island. I spent my first days in the Truku Indigenous community of Skadang. They welcomed me to their community and Presbyterian Church like a returning family member. I marvelled at how they continued with church services, barbecues, and collective drinking with neither masks nor social distancing, as if the epidemic had never existed. When someone asked me with concern if Holo people had "forced" me to "hold incense" (pray), she pointed out the emotionally salient religious divide between Buddhist-Taoist Holo and Indigenous Christian lifeworlds.

On 20 May, President Tsai's inauguration ceremony was an online and televised event, rather than a public ceremony. Tsai began her speech by thanking citizens for cooperating in the fight against COVID-I9, highlighting those who accepted quarantine or isolation to prevent possible spread of the virus. Discretely linking Taiwan's battle against COVID-I9 to its geopolitical challenges, she said: "The path forward will not be easy, and greater challenges await us. But we are a country that has persevered through even the greatest hardships. We, the 23 million people, have always been and will always be a community with a shared destiny" (Tsai 2020).

Tsai's speech was not the only public affirmation of sovereignty that week. On 22 May, the Indigenous Paiwan of Kapanan on the Hengchun Peninsula marked the anniversary of the I874 Battle of Stone Gate in a new way. In I87I, sailors from Ryūkyū (Okinawa) were shipwrecked, and 54 of them were murdered by Paiwan warriors. After China's Qing Dynasty refused to take responsibility, saying that the actions of Formosan "savages" are beyond their jurisdiction, Japan launched a punitive expedition on 22 May 1874. After six months of stalemate, during which the Japanese lost more troops to malaria than to battle, the Qing accepted responsibility and agreed to pay compensation. This turn-of-events was decisive in Asian geopolitics, as it was the beginning of China's claims over all of Taiwan and Japan's claim over Ryūkyū. Official Mudan ("peony") Township commemorations always focus on the I87I events as an expression of savage head-hunting traditions, framing the subsequent international agreement between China and Japan as the triumph of rational statecraft over savagery. They called it the "Mudan Incident" after the Chinese name for the place. State-centric leaders celebrate the fact that the ROC inherited governance from Japan; and even modernize this form of 
governmentality by incorporating Indigenous leaders as citizens and political actors. They remain silent about a similar I867 "Rover Incident," in which a failed American punitive expedition led to a treaty between the Paiwan and the United States as ontological equals. Such a framing obscures both Okinawan and Paiwan subjectivities.

This year, the Kapanan Community Development Association (KCDA) held an alternative event at the same time, just around the corner. Their goal was to affirm Paiwan sovereignty in an event they called "sevalitan." KCDA chairperson Cudjuy Isumalji explained the meaning of the word, which can denote ancestor, ancestral spirit, or even descendant, but at the most profound level signifies a transition from one state to another. The ritual included shamanic prayer, shooting rifles to memorialize different historical turning points, a pig sacrifice, and smoke signals (Figure 5). The smoke signals, known as langyan (lit. "wolfsmoke"), are used in Taiwan's pan-Indigenous social movement as a symbol of Indigenous sovereignty. Kapanan youth re-enacted the historical events in a theatrical work depicting their resistance against invasion. Paiwan Indigenist leaders would like to change the name of Mudan Township to one that reflects Paiwan culture and political sovereignty. Eventually, they would like to establish Indigenous self-government. Sevalitan thus represents hope of a transition from a colonial situation to recognition of their unceded sovereignty. As Taiwan emerged from the threat of COVID-I9, leaders made powerful, yet conflicting, ontological claims about what is Taiwan. President Tsai affirmed a place for

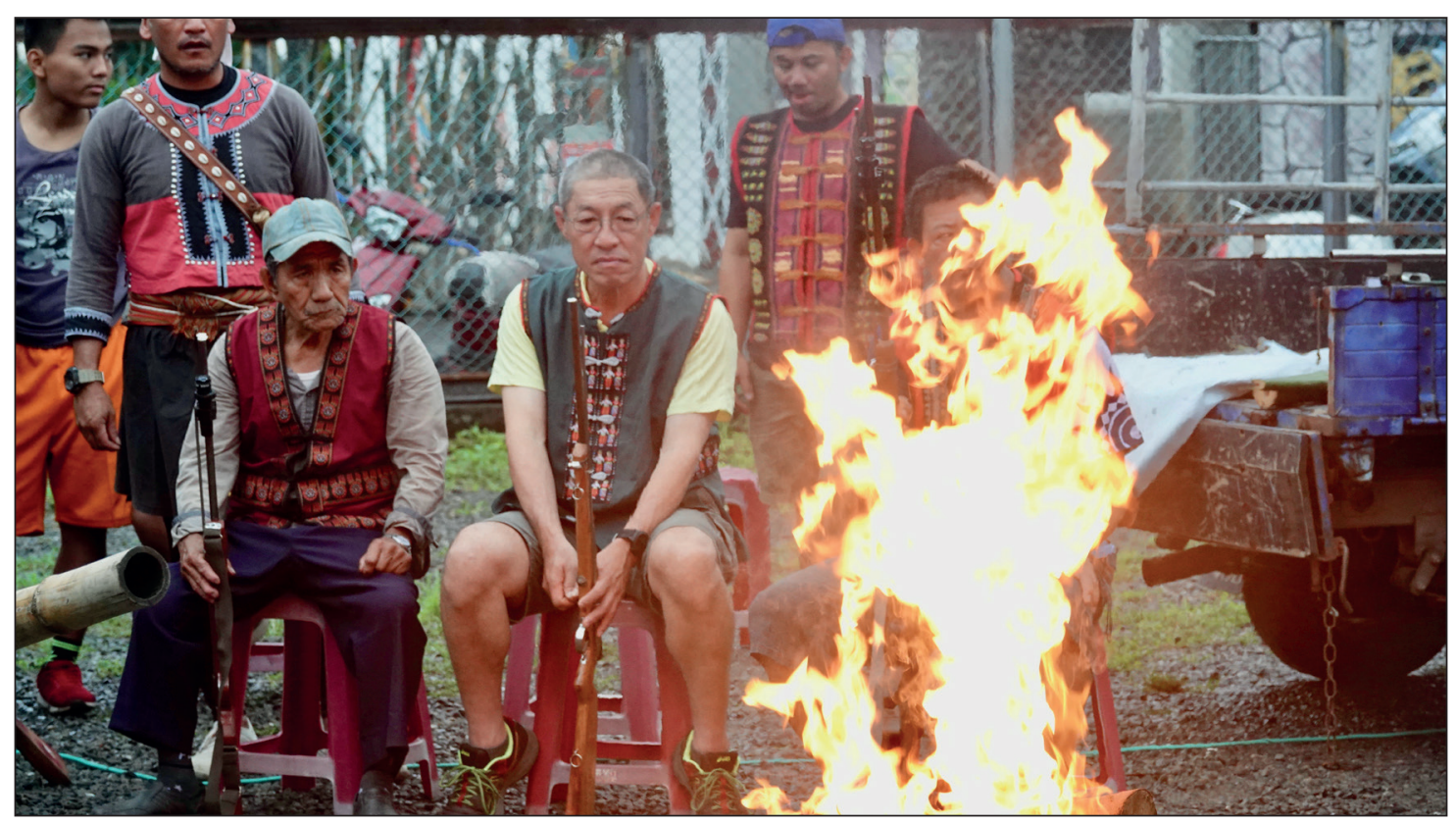

Figure 5: Lighting the Fire for Indigenous Sovereignty, Kapanan, 22 May. Photo by author. 
Taiwan in the Westphalian system. Mudan Township authorities of Paiwan Indigenous identity, who do not necessarily share Tsai's agenda of affirming and independent identity for Taiwan, asserted their place within the Republic of China. Grassroots activists stressed that Taiwan is being constructed on unceded Indigenous territory.

A week later, my father-in-law drove me to nearby Kenting National Park. At my request, we stopped to visit the grave of the 54 Okinawan sailors. Our trip ended at Eluanbi, the southern tip of Taiwan where a lighthouse had been erected in I882. I smiled when I read the information board explaining that its purpose was "to prevent foreigners from colluding with aborigines." My fatherin-law was amazed that I was more familiar than he with both Indigenous history and the roads we travelled. I could also perceive a difference in our understandings of geography. After two decades of Indigenous research, I imagined that we were travelling from Holo-controlled to unceded Paiwan territory. In his minds eye, we were simply driving around Taiwan. This is an ontological difference, as he moves from temple to temple through the world as Taiwanese; whereas I have absorbed Indigenous ontology into my perceptions of the same landscapes. The plaque was a good reminder that I am not the first foreigner to have ever entertained such thoughts. As an anthropologist, I can document these stories in both their telling and in their enactment, especially as stories and practice reveal a Political Ontology of world-shaping (Blaser 2009, 877).

\section{June: From Epidemic Anxiety to Race-Based Activism}

In June, as the number of days without local infections exceeded 50, COVID-I9 worries receded. Taipei held the only LGBTQ+ Pride Parade in the world, when all other countries cancelled due to COVID-I9. Dragon Boat festivities and races continued as normal (Figure 6), albeit with ubiquitous masks, temperature checks and requests to leave cellphone numbers for contact tracing. In this context, I could travel, socialize, and eat in restaurants as normal, conscious that those pleasures would end after my return to Canada.

As people in North America turned their attention to racial inequalities and the Black Lives Matter protests against police violence, some people in Taiwan spoke out about discrimination against Indigenous peoples. I was reminded of that reality when I went to Hualien for the funeral of Kuhon Sibal, who had been a gracious host and intellectual collaborator during my research trips in his village. Stopping in Hualien City to visit his sister Igung Sibal, the seasoned activist who first invited me to study Indigenous Taiwan, I was so distracted by 
emotion that I accidentally knocked on the neighbour's door. "I'm sorry," I said. "I was looking for Tien Chun-chou (Igung's Chinese name)."

"Who?" barked the man in the living room.

"Tien Chun-chou," I said.

"Who?" he cried.

Suddenly his wife called out from the kitchen in Holo, "Hoan-a!" ("the savage").

I hurriedly scuttled next door without further explanation. Calling her neighbour "savage" is a violent form of exclusion.

On 13 June, about 500 people gathered in Taipei in support of Black Lives Matter. Savungaz Valincinan, a young Bunun woman from the Indigenous Youth Front, took the stage to describe discrimination faced by Indigenous people in regard to rental accommodations and other issues. She said, "We are coming out today to support this movement not because of sympathy. It is because we have also gone through the hurt of being discriminated against" (Reuters 2020). Facebook discussions by Taiwan Indigenous social activists likewise turned to problems of discrimination. I contributed my anecdote about visiting Igung.

On that day, I attended a meeting with the Indigenous Taiwan SelfDetermination Alliance (ITSDA) and the Seediq National Council in Puli to discuss future research on territory and self-determination. Because the ITSDA is part of an emerging pan-Indigenous social movement, Cudjuy (above) also drove up from Paiwan Territory to join us and show his support. In the afternoon, I went with Seediq participants to the community of Tongan. We passed through a narrow canyon marked with a sign in Chinese that we have reached Renzhiguan, the "pass where people stop." The place name still recalls the past when non-Indigenous people dared not enter Indigenous territory. Rural-based Indigenous activists, like the people I was with, describe Renzhiguan as the gate to Seediq national territory. But, as Taiwan's epidemic disappeared, but international travel was still impossible, Taiwanese tourists started heading up the same roads. When I visited Boalung higher in the mountains, employees at the nearby Qingjing Farm told me that hotels are running at full capacity. Seediq activists wondered how they could regain this lost territory, now administered by the Veteran's Affairs Council. Again, there are important ontological differences to note. Whereas non-Indigenous Taiwanese treat the mountains as their 
playgrounds, the Indigenous peoples have a very different relationship with the land. For the Seediq, the mountain forests (dgiyaq) are hunting grounds, imbued with spiritual relations with the ancestors (utux). The Paiwan call their hunting grounds qaqaljupan, and are just as aware of how much has been lost over history to both Japanese and Chinese settlers.

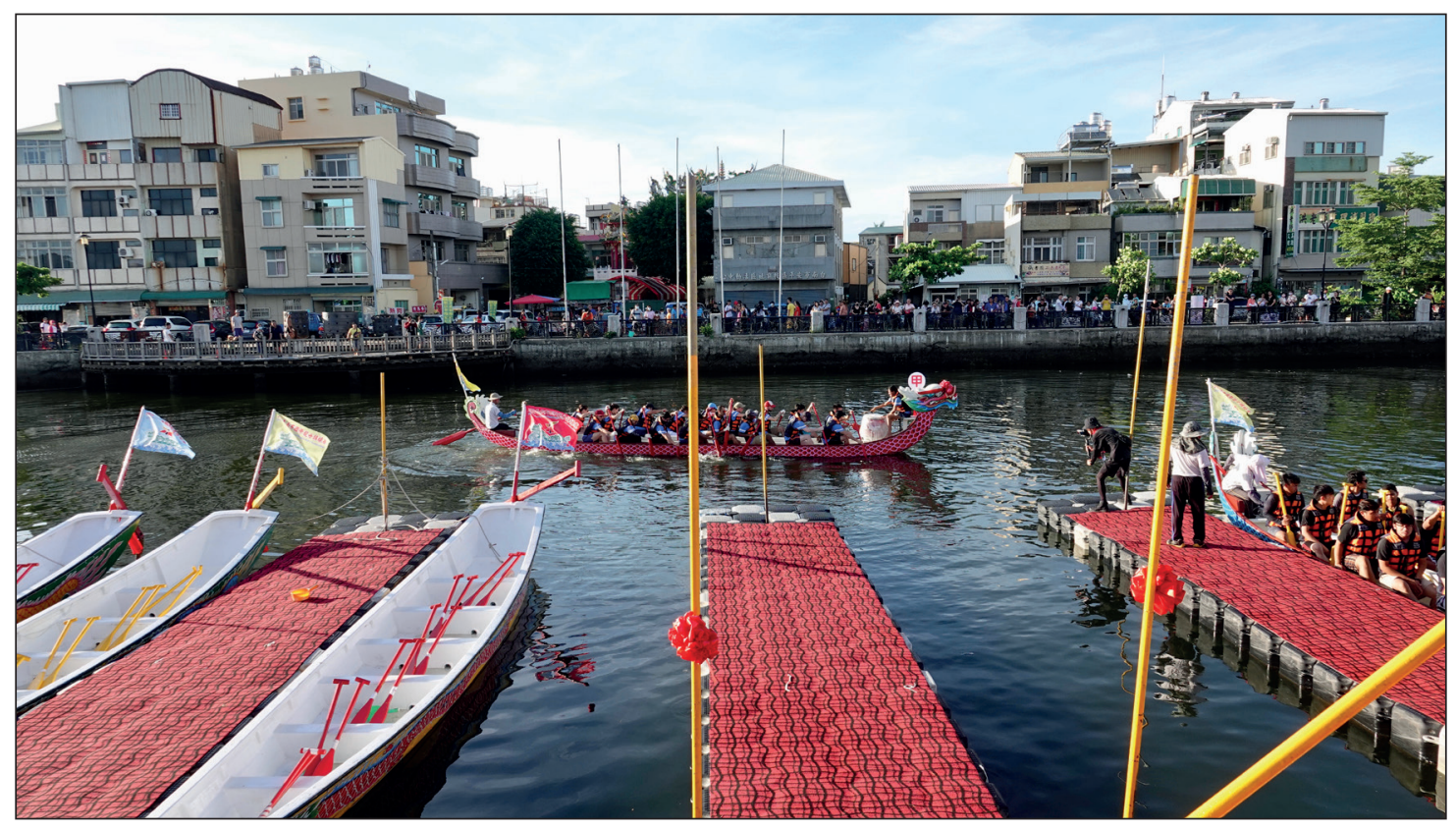

Figure 6: Dragon boat festival, Tainan, 25 June. Photo by author.

\section{July: Final Thoughts as I Return Home}

Reading in the New York Times that $75 \%$ of White Americans have no Black friends, I began to wonder if the same holds for relations between nonIndigenous and Indigenous people in Taiwan. A few days before leaving, I started asking people if they have Indigenous friends. Frankly, I was not surprised when people said no. One woman offered the explanation that "they are all illtempered, so it's not easy to make friends with them." On my taxi ride to the High-Speed Rail, I asked the driver. He said that he knew Indigenous people when he was in the military, but no longer Indigenous friends. "It's impossible," he said revealingly, "because we don't speak the same language." Even as I proffered, "but you all speak Mandarin," I realized that I was asking this Holo speaker to speak in his private life what is to him a foreign language and a political imposition. Ever since I arrived in March, people had been trying to communicate to me their different ways of worlding Taiwan, practices that I observed happening in Holo, Paiwan, and Truku languages. COVID-I9 is a new element 
in ever unfolding processes of world-making, but it would be surprising if it did not have an effect on geopolitics. The Holo were teaching me that relations between Taiwan and China are international relations. Indigenous activists reminded me that that relationships between Indigenous and non-Indigenous peoples are also geopolitics. These are all ontological claims.

\section{Geopolitical Conclusions}

Stories told about COVID-I9 contribute to practices of world-shaping. In my brief stay in Taiwan, I could see this in the way that some Taiwanese people wore masks, which not only prevented infection, but also demonstrated social solidarity against the China Virus. This world-shaping behaviour complements simultaneous practices in temples that also include demarcating territory, monitoring behaviour, and remaining vigilant about foreign bodies. Indeed, Taiwanese people may have easily adopted such behaviour because it was consistent with pre-existing ontologies of disease. I also saw world-shaping in the way some Indigenous people refused to wear masks, insisting that they collectively can already resist the virus. These social worlds co-exist, mingle, and even co-evolve, but they have undeniable political implications and there are conflicts between them.

These stories and practices give us a glimpse into different ontologies of disease. In Taiwan, the dominant ontology is that disease is a foreign entity that must be expelled by social means. This differs starkly with the dominant ontology in Northern Europe and North America that the disease is a part of nature that must be mastered by the science of vaccines. The result is that Taiwan's CDC has succeeded (so far) in keeping the coronavirus at bay. The fact that Taiwan was already vigilant toward China, which they saw as the most likely source of danger, probably contributed to that success. Taiwan's Indigenous peoples have yet other ontologies of disease. To the Seediq-Truku, and probably others, disease only takes a place when a community has lost its internal spiritual equilibrium. In the current context, they are building up community cohesion through their own rituals, like the Paiwan Sevalitan, and demands for recognition of their sovereignty.

In terms of Political Ontology, the most pressing issue in the long term is not a virus. It is the ontological status of Taiwan itself. Chinese leaders make an ontological claim when they insist that Taiwan is a wayward Chinese province; Taiwanese leaders press back with effective anti-COVID measures, but also with soft diplomacy around the world. Indigenous leaders struggle to find a place 
for their peoples and demands for sovereignty within this context, even as Chinese leaders call them "national minorities" and Taiwanese leaders try to encapsulate them in multicultural Indigeneity. What it means to be Taiwan is an ontological question; as is what it means to be Indigenous. Anthropologists can interpret all of this in terms of conflictual practices of worlding. This is why Appadurai's argument is so appealing, even though I think it is a bit romantic to believe that COVID-I9 can weaken the Westphalian state and put society in charge. If Taiwan is knocking at the doors of the Westphalian system, it is because the Taiwanese wish to be admitted to the international system as equals to other states. Public health measures, as well as military preparations and diplomatic campaigns, are worlding practices, ways of becoming a nation-state that are not reducible to any avatar of "Greater China" and which justify international recognition on their own terms. Since China is also evolving towards exclusive Westphalian notions of statehood and sovereignty, however, the risk of violent conflict is increasing. At the same time, Taiwan's Indigenous peoples, aware of their past as what Pierre Clastres (1977) so famously called "society against the state," are affirming other kinds of sovereignty. COVID-I9 is now part of these worlds; and may very well act as a catalyst for lasting political change in post-pandemic international relations.

\section{Scott Simon,}

University of Ottawa, ssimon@uottawa.ca

\section{Acknowledgments}

I am grateful to family and friends for their generosity and for sheltering me in the early months of the COVID-I9 pandemic. Research in Guam and Taiwan that nourished these reflections has been funded by the Social Sciences and Humanities Research Council of Canada.

\section{Notes}

I I lived in Taiwan from 1996 to 200I, during which time I did two research projects with these Holo in Tainan (Simon 2003) and an ethnically diverse population of women entrepreneurs in Taipei (Simon 2005). Since 200I, I have done research on indigeneity, including three years of field research in four Seediq or Truku communities and annual visits. My book on indigenous-state relations was published in 2012 (Simon 20I2a). 
2 Canada had diplomatic relations with the Republic of China on Taiwan until October I970, when Canada recognized the People's Republic of China (PRC) as the government of China. Recognizing that Taiwan was a separate political reality, Canada refused to endorse the PRC claim to Taiwan, which it did not govern. The absence of formal diplomatic relations between Canada and Taiwan did not prevent a subsequent flourishing of economic, social, and even substantive state-to-state relations between Canada and Taiwan.

3 Fate (ming) and luck (yun), the two sides of a life's destiny (mingyun) are staple concepts of the old sino-centric (China-centric) ethnographies of Taiwan. P. Steven Sangren notes that an obsession with luck and fate is a distinguishing characteristic of Chinese culture, but is best understood as a universal human desire to assert agency (Sangren 2012, II7). In this case, as well as the above reference to China's policy of restricting movement to Taiwan during the election, good luck (yunqi) refers to the unintended good consequences of decisions made for other reasons. Luck is thus a way of discussing the unpredictability of life.

\section{References}

Appadurai, Arjun. 2020. "The COVID Exception.” Social Anthropology 28 (2): 22I-222. https://doi.org/IO.IIII/I469-8676.I2898.

Barclay, Paul. 20I8. Outcasts of Empire: Japan's Rule on Taiwan's “Savage Border," I874-I945. Oakland, CA: University of California Press.

Blaser, Mario. 20I4. "Ontology and Indigeneity: On the Political Ontology of Heterogeneous Assemblages." Cultural Geographies 2I (I): 49-58. https://doi. org/IO.II77/I474474OI2462534.

Blaser, Mario. 2009. "Political Ontology: Cultural Studies without 'Cultures'?" Cultural Studies 73 (5-6): 873-896. https://doi.org/I0.I080/09502380903208023.

Blaser, Mario, and Marisol de la Cadena. 20I8. "Introduction: Pluriverse Proposals for a World of Many Worlds." In A World of Many Worlds, edited by Marisol de la Cadena and Mario Blaser, I-22. Durham, NC: Duke University Press.

Braun, Bruce. 2007. "Biopolitics and the Molecularization of Life." Cultural Geographies I4 (I): 6-28. https://doi-org.proxy.lib.sfu.ca/IO.II77/I4744740070728I7.

Brown, Melissa. 2004. Is Taiwan Chinese? the Impact of Culture, Power, and Migration on Changing Identities. Berkeley: University of California Press.

Callahan, William A. 2004. Contingent States: Greater China and Transnational Relations. Minneapolis: University of Minnesota Press. 
CDC. 2020. “The Facts Regarding Taiwan's Email to Alert WHO to Possible Danger of COVID-I9." Taiwan Centers for Disease Control. April II. Accessed November I3, 2020. https://www.cdc.gov.tw/En/Bulletin/Detail/PAD-lbwDHeN_bLa-viBOuw? typeid=I58.

Chen, Yen-Fu. 2020. "Taiwan and the World Health Assembly/World Health Organization: Perspectives from Health Services and Research.” International Journal of Taiwan Studies 3 (I): IO-27. http://doi.org/IO.II63/24688800-0030I003.

Clastres, Pierre. 1977. Society Against the State. Translated by Robert Hurley. Oxford: B. Blackwell.

Cole, J. Michael. 2020. "How Taiwan is Leading by Example in the Global War on the COVID-I9 Pandemic.” Macdonald-Laurier Institute Commentary. Accessed July 8, 2020. https://macdonaldlaurier.ca/files/pdf/MLICommentary_March202O_Cole_ FWeb.pdf.

Descola, Philippe. 20I4. Beyond Nature and Culture. Translated by Janet Lloyd. Chicago: University of Chicago Press.

Donggangzhen, Haigong. 2020. "Wuhan Feiyan [Wuhan Pneumonia]." Facebook. Accessed November I3, 2020. https://www.facebook.com/seven8327777/ posts/202888567729202/.

Festa, Paul. 2007. "Mahjong Agonistics and the Political Public in Taiwan: Fate, Mimesis, and the Martial Imaginary." Anthropological Quarterly 80 (I): 93-I25. http://doi. org/IO.I353/anq.2007.0004.

Gates, Hill. 198I. "Ethnicity and Social Class." In The Anthropology of Taiwanese Society, edited by Emily Martin Ahern and Hill Gates, 24I-28I. Stanford; Stanford University Press.

Katz, Paul. 1987. "Demons or Deities? The Wangye of Taiwan.” Asian Folklore Studies 46 (2): I97-2I5.

Katz, Paul. 1995. "The Pacification of Plagues: a Chinese Rite of Affliction.” Journal of Ritual Studies 9 (I): 55-IOO.

Keck, Frédéric. 2015. "Sentinels for the Environment: Birdwatchers in Taiwan and Hong Kong." China Perspectives I02: 43-52. https://doi.org/I0.400o/chinaperspectives. 6723. 
Kojima, Yoshimichi. 2003. Fanzu Guanxi Diaocha Baogao Shu, Di wu juan, Paiwanzu, di san ce. [Report on the Customs of Savage Tribes, Volume 5: Paiwan Tribe, Number 3]. 1920. Translated by Institute of Ethnology, Academia Sinica. Taipei: Academia Sinica Institute of Ethnology.

- _. I996. Fanzu Guanxi Diaocha Baogao Shu, Di yi juan, Taiyazu [Report on the Customs of Savage Tribes, Volume I: Atayal Tribe]. 1915. Translated by Institute of Ethnology, Academia Sinica. Taipei: Academia Sinica Institute of Ethnology.

Lo, Ming-Cheng M. 2020. "How Taiwan's Precautionary Approach Contained COVIDI9." Contexts I9 (4): I8-2I. https://doi.org/IO.II77/I536504220977929.

MOI (Ministry of the Interior). 2020. "Xia-Qieding Jinluangong Wangjiao Dadian [The Wangye Rituals of Lower Qieding's Jinluangong].” Taiwan Zongjiao Wenhua Zichan [Taiwan's Religious Cultural Heritage]. Accessed November I3, 2020. https://www. taiwangods.com/html/cultural/3_ooII.aspx?i=I72.

Murray, Stephen O., and Keelung Hong. 1994. Taiwanese Culture, Taiwanese Society: A Critical Review of Social Science Research Done on Taiwan. Lanham, MD: University Press of America.

Rawsley, Ming-yeh. 2020. “Editorial." International Journal of Taiwan Studies 3 (I): I-3. https://doi.org/IO.II63/24688800-0030I0oI.

Reuters. 2020. "Taiwan Black Lives Matter Protest gets Indigenous Twist." Reuters. Accessed November I3, 2020. https://www.reuters.com/article/us-minneapolispolice-protests-taiwan/taiwan-black-lives-matter-protest-gets-indigenous-twistidUSKBN23KoCE.

Robertson, Grant. 2020. "What Happened with Canada's Pandemic Alert System? The GPHIN Controversy Explained." Globe and Mail. October 5. Accessed Novemberı, 2020. https://www.theglobeandmail.com/canada/article-what-happened-withcanadas-pandemic-alert-system-the-gphin/.

Sangren, P. Steven. 2012. "Fate, Agency, and the Economy of Desire in Chinese Ritual and Society." Social Analysis 56 (2): II7-I35. https://doi.org/IO.3I67/sa.20I2.560209.

Simon, Scott E. 20I2b. "Politics and Headhunting among the Formosan Sejiq: Ethnohistorical Perspectives." Oceania 82 (2): I64-I85. https://doi.org/I0.IOO2/j.I834446I.20I2.tbooI27.x.

___ 20I2a. Sadyaq Balae! L'autochtonie formosane dans tous ses états. Québec: Presses de l'Université Laval. 
- - 2003. Sweet and Sour: Life-worlds of Taipei Women Entrepreneurs. Lanham, MD: Rowman \& Littlefield.

- - 2005. Tanners of Taiwan: Life Strategies and National Culture. Boulder: Westview Press.

Tsai, Ing-wen. 2020. "Full Text of Taiwan President Tsai Ing-wen's Second-term Inaugural Address." Focus Taiwan CAN English News. Accessed November 13, 2020. https://focustaiwan.tw/politics/202005200003.

Viveiros de Castro, Eduardo. 2009. Métaphysiques cannibales: Lignes d'anthropologie post-structurale. Paris: Presses universitaires de France.

$\mathrm{Xu}$, Guozhen. 2020. "Zhongshi Gongmiao Ban Fahui: Qing Ouwen Wangye Songzou Wuhan Feiyan [Taichung Public Temple Holds Ceremony: Asking the Plague Expeller Wangye to Send Away Wuhan Pneumonia]." Ziyou Shibao [Independence Times]. April 19. Accessed November 13, 2020. https://news.ltn.com.tw/news/life/ breakingnews/3138728. 